\title{
The Physicochemical Potentials of Water from Bore Holes, Tube Wells, Water Harvesters, Water Hawkers and Direct Fetching from Open Water Sources Like Lakes and Rivers in Makurdi Benue State and Keffi, Nasarawa State Nigeria. A Quest for Sustainable Development Goal 6 (Ensuring That Everyone has Access to Safe Water by 2030)
}

\author{
Beetseh C. I ${ }^{1}$ Audu S. S ${ }^{2}$ Kondoun D. A ${ }^{3}$ \\ Department of Chemistry University of Agriculture Makurdi. \\ Department of Science Laboratory Technology Nasarawa State University Keffi
}

\begin{abstract}
World Water Day- 22 March 2018 with the theme 'Nature for Water' - is exploring nature-based solutions to the water challenges we are facing in the 21st century. The Sustainable Development Goal 6 committed the world to ensure that everyone has access to safe water by 2030 .Looking around our environment are simple but definite sources of water that can generate up to 50001 water or more at a time year round. Some boreholes, rivers, tube wells, water harvesters, water hawkers and direct fetching from open water sources like lakes and rivers within 2 areas Keffi Nasarawa State and Makurdi Benue State Nigeria were sampled and analysed for physicochemical and bacterial load properties. Results are displayed side by side the WHO /Nigeria Guidelines for Drinking Water standards 2005 .Relatively high values are recorded for total solids, total hardness ,color, conductivity and bacterial load per $100 \mathrm{ml}$ in both cities which can be treated with simple and available water treatment equipment. Sustainable Development Goal 6 ensuring that everyone has access to safe water by 2030 is realizable and affordable if the proper will is in place.
\end{abstract}

Keywords: Sustainable, Guidelines, physicochemical, water and equipment

DOI: $10.7176 / \mathrm{CMR} / 11-4-02$

Publication date: April $30^{\text {th }} 2019$

\subsection{Introduction}

Excluding fat, water composes approximately $70 \%$ of the human body by mass. It is a crucial component of metabolic processes and serves as a solvent for many bodily solutes. At room temperature, water is a tasteless and odorless liquid, nearly colorless with a tint of blue. Its melting point is $0^{\circ} \mathrm{c}$, boiling point $99.98^{\circ} \mathrm{c}, 96 \%$ of water is found in oceans, the rest is found in fresh waters, ice, in the atmosphere and ground water. It is a good solvent, dissolves salts, sugars and gases. Pure water is a bad conductor on its own but dissolves ionic substances and becomes a good conductor. In nature and in use it is rarely pure and some of its properties may vary slightly from those of the pure substance. However, there are many compounds that are insoluble in water and it is the only common substance found naturally in all three common states of matter and it is essential for all life on Earth. Water is also a good solvent due to its polarity. Substances that will mix well and dissolve in water (e.g. salts) are known as hydrophilic ("water-loving") substances, while those that do not mix well with water (e.g. fats and oils), are known as hydrophobic ("water-fearing") substances. Wiley, 2009 According to the BrønstedLowry definition, an acid is defined as a species which donates a proton $\left(\mathrm{a} \mathrm{H}^{+}\right.$ion) in a reaction, and a base as one which receives a proton. When reacting with a stronger acid, water acts as a base; when reacting with a stronger base, it acts as an acid. For instance, water receives an $\mathrm{H}^{+}$ion from $\mathrm{HCl}$ when hydrochloric acid is formed:

$\mathrm{HCl}$ (acid) $+\mathrm{H}_{2} \mathrm{O}$ (base) $* \mathrm{H}_{3} \mathrm{O}^{+}+\mathrm{Cl}-$

In the reaction with ammonia, $\mathrm{NH}_{3}$, water donates a $\mathrm{H}+$ ion, and is thus acting as an acid:

$\mathrm{NH}_{3}$ (base) $+\mathrm{H}_{2} \mathrm{O}$ (acid) $\stackrel{\mathrm{NH}^{+}}{\longrightarrow}+\mathrm{OH}^{-}$

i

ii

Because the oxygen atom in water has two lone pairs, water often acts as a Lewis base, or electron pair donor, in reactions with Lewis acids, although it can also react with Lewis bases, forming hydrogen bonds between the electron pair donors and the hydrogen atoms of water. HSAB theory describes water as both a weak hard acid and a weak hard base, meaning that it reacts preferentially with other hard species:

$\mathrm{H}^{+}$(Lewis acid) $+\mathrm{H}_{2} \mathrm{O}$ (Lewis base) $\rightarrow \mathrm{H}_{3} \mathrm{O}$

$\mathrm{Fe}^{3+}$ (Lewis acid) $+\mathrm{H}_{2} \mathrm{O}$ (Lewis base) $\rightarrow \mathrm{Fe}\left(\mathrm{H}_{2} \mathrm{O}\right)^{3+}$

$6 \mathrm{Cl}-$ (Lewis base) $+\mathrm{H}_{2} \mathrm{O}$ (Lewis acid) $\rightarrow \mathrm{Cl}\left(\mathrm{H}_{2} \mathrm{O}\right)^{-6}$

iii

iv

$\mathrm{v}$

When a salt of a weak acid or of a weak base is dissolved in water, water can partially hydrolyze the salt, producing the corresponding base or acid, which gives aqueous solutions of soap and baking soda their basic $\mathrm{pH}$ : 
$\mathrm{Na}_{2} \mathrm{CO}_{3}+\mathrm{H}_{2} \mathrm{O}=\mathrm{NaOH}+\mathrm{NaHCO}$

Water can also be electrolyzed into oxygen and hydrogen gases but in the absence of dissolved ions this is a very slow process, as very little current is conducted. While electrons are the primary charge carriers in water (and metals), in ice the primary charge carriers are protons Water can be split into its constituent elements, hydrogen and oxygen, by passing an electric current through it. This process is called electrolysis. Water molecules naturally dissociate into $\mathrm{H}+$ and $\mathrm{OH}-$ ions, which are attracted toward the cathode and anode, respectively. At the cathode, two $\mathrm{H}^{+}$ions pick up electrons and form $\mathrm{H}_{2}$ gas. At the anode, four $\mathrm{OH}^{-}$ions combine and release $\mathrm{O}_{2}$ gas, molecular water, and four electrons. The gases produced bubble to the surface, where they can be collected. The standard potential of the water electrolysis cell is $1.23 \mathrm{~V}$ at $25^{\circ} \mathrm{C}$. Nic M. et al 2006. Water has other names; the simplest systematic name of water is hydrogen oxide. This is analogous to related compounds such as hydrogen peroxide, hydrogen sulfide, and deuterium oxide (heavy water). Another systematic name, oxidane, is accepted by IUPAC as a parent name for the systematic naming of oxygen-based substituent groups, although even these commonly have other recommended names. Hydroxyl is recommended over oxidanyl for the $-\mathrm{OH}$ group. The polarized form of the water molecule, $\mathrm{H}^{+} \mathrm{OH}^{-}$, is also called hydron hydroxide by IUPAC nomenclature.

Potable water is water pure enough to be consumed or used with low risk of immediate or long term harm. Some health authorities have suggested at least eight glasses of water per day. The current low level access to clean water and safe sanitation across the country has affected the health and living condition of the population, particularly the urban poor population. Financial resources and sustainability has raised public and political awareness which led Kofi Annan, former UN Secretary General (now late) to place the issues of clean water, basic sanitation and good hygiene firmly in the public consciousness and on the political agenda. Potable water seems to be the main focus and a reasonable amount of work is been done towards it. The African Development Bank ADB is funding Water Schemes of Taraba and Oyo States which the Federal Government borrowed $\$ 1.137$ billion from the Islamic Development Bank (IDB), the International Development Association (IDA), French Development Agency (FDA) and Indian Line of Credit. The loans are in line with Nigeria's external borrowing guidelines and are meant for economic and power reforms, rural development, special intervention for infrastructural development in some states and social programme development in others. Among the objectives of the project are safe and adequate water supply and sanitation services as a key instrument for fighting poverty and accelerating socio-economic development in the National Economic Empowerment and Development Strategy (NEEDS) and State Economic Empowerment and Development Strategy (SEEDS). Chemistry for Water, Perspectives and Recommendations was the theme at an International Conference on Chemistry for Water. (Maison de la Chimie Foundation 2004). Several contributors drew attention to the dreadful reality of 5000 children dying due to lack of water every day. It became imperative that what is required is effective management of water resources, an important strategy for sustainable socio-economic development, which is especially critical for developing countries. Nigeria Water Resources Vision 2025 is an offshoot of the larger African Vision that has water quality and sanitation as key components. In Anambra State, the EU in 2009 and 2010, funded the construction of water supply and sanitation facilities in 179 rural communities, 10 small towns and 2 urban communities, at a total cost of Naira 535 million. Between 2006 and 2008, the EU, through the Water Supply and Sanitation Sector Reform Programme (WSSSRP) in Anambra State, funded the institutional restructuring of the Anambra State Water Corporation and supported the creation of the new Ministry of Public Utilities, Water Resources and Community Development. The EU, in 2008, co-financed, to the tune of N100 million, the rehabilitation and expansion of the Amawbia Water Supply Scheme. Alhaji Buhari the president of Nigeria had to declare a state of emergency on water and sanitation in the country late 2018 considering the fact that potable water had not even reached everyone yet considering the supposedly lofty multibillion Naira water projects already embarked upon in immediate past, citizens are still largely exposed to non potable water sources in the country. [AIT News Nigeria Friday $9^{\text {th }}$ Nov 2018]

\section{Water Position in Keffi and Makurdi}

\subsection{Keffi North Central Nigeria}

Keffi is one of the oldest towns in North Central Nigeria dating back to the $19^{\text {th }}$ century serving as administrative as well as religious headquarters .It harbours the Nasarawa State University and many higher institutions and was supplied with water coming mainly from the State Central Water Treatment Facility at Gudi.46kms from Akwanga. Water was running in public taps in the town and the institution which is now Nasarawa State University Keffi NSUK. That was then, that facility is no more functional due to in availability of materials and equipment, obviously because of lack of funds and political will. Today individual boreholes are seen and water tankers giving water in the metropolis and the surroundings including the university ( Nasarawa State University Keffi -NSUK) The old water works $3 \mathrm{~km}$ to Keffi from Akwanga as well as the Antau river within Keffi itself cannot give the desired quantity even for treatment. The university now enjoys water curtsey of a well spirited philanthropist General T Y Danjuma's water project right within the campus giving one million L water capacity. 
Now maintenance, resources and power issues have made its operation epileptic. Water tankers as well as bore holes are handy.

\subsection{Makurdi Central Nigeria}

In Makurdi Benue State, sources of water include the River Benue - a large body of water with capacity to cater for the water needs of over five cities together. River Benue passes through the metropolis and is accessible all the year round on all sides. Some inhabitants of the city fetch direct from the River but the State Government through its water Ministry operates a water treatment plant which uptakes the water for treatment. The State Government recently constructed the greater Makurdi water works with a capacity of $50,000 \mathrm{~m}^{3} /$ day or 2,100 $\mathrm{m}^{3} / \mathrm{h}$, during 24 hours of operation. At the second phase, the treatment plant will have a capacity of $100,000 \mathrm{~m}^{3} /$ day or $4,200 \mathrm{~m}^{3} / \mathrm{h}$ (Gilmore Engineering 2013). Even at full capacity in the second phase this treated water will not be enough for the end users because of distribution constraints and expansion of the town . Bore holes and tube wells as alternative water sources will still be in demand and services of water hawkers are seen all over the metropolis carrying water in 20 liter containers packed in hand driven trucks for sale. The situation in the rural areas of Benue is not so different. Water schemes are spread over the state mainly bore holes, tube wells and dams provided by government, organizations and individuals.

\section{Significance of this Work}

Sustainable Development Goal 6, ensuring that everyone has access to safe water by 2030 is realizable if efforts are stepped up to get together a number of issues that have so far made a mirage of this goal. Chief is deliberate political will to put up a robust investment in both equipment and manpower in order to explore and maintain maximum water supply which includes replacement or prompt servicing of machinery, training and retraining of personnel, research and development. The will has always being there but the follow through has some difficulty because of the down turn of the economy which is where we are. World Water Day- 22 March 2018 with the theme 'Nature for Water' - is exploring nature-based solutions to the water challenges we are facing in the $21^{\text {st }}$ century with the Sustainable Development Goal 6 committing the world to ensure that everyone has access to safe water by 2030 . If we identify water sources around our vicinities, test their quality and compare it to WHO /Nigeria Guidelines for Drinking Water standards 2005, the present day economy can be redirected to simpler methods of acquiring and treating these simple sources of water- bore holes, tube wells, water harvesters, water hawkers and direct fetching from open water sources like lakes and rivers by coagulation, filtration and disinfection. This investigation focuses on the Makurdi and Keffi environments.

\section{Methodology}

All containers in these stations labeled KF for Keffi and Mk for Makurdi were taken in 20-L plastic cans already rinsed with the sample water; their measurement was done by hand held equipment already standardized for the purpose at Greater Makurdi Water Works Central laboratory. Each sample was a composite sample of 3weeks apart sampling from all the sources. Altogether 3 samples were analysed for each parameter and the results are mean values.

Hach Company DR3900 Spectrophotometer with Radio Identification [RF I D]. A work book of testing procedures.TDS meter (model 50150 from Hach Company).

Spectrophotometer DR/2000 from Hach company the program number (120) for colour.

The hardness test kit model Ha-4p-mg-l was used.

$\mathrm{pH}$ meter from Hanna company .

Dissolve oxygen meter (model 9071 made by the Hach Company) was used .

The following physicochemical parameters were considered -Temperature oC. Color, Pt.co Conductivity(Mhos) , pH, Total Hardness , mg/L Total dissolved Solids mg/L, Total dissolved Solids mg/L, Dissolved Oxygen and Bacterial Load per $100 \mathrm{ml}$ water.

Results and other data are displayed at the appendix after references.

\section{Observations and Discussion}

Results are displayed side by side the WHO /Nigeria Guidelines for Drinking Water standards 2005. Relatively high values are recorded for total solids, total hardness, color, conductivity and bacterial load per $100 \mathrm{ml}$ in Makurdi as well as Keffi. The streams in keffi - Antau and Old Water Works are seasonal and therefore not accessible in the dry season. Large rivers like River Benue and even small ones like Antau in Keffi are polluted with sewage effluent, surface runoff, pollutants from sources far upstream, small streams, springs and wells contaminated by animal waste and pathogens. Such microscopic larvae are ingested and can form potentially life threatening cysts in the brain or liver. This risk extends to plants grown around the water side. The following methods are however in use in water purification at different levels and can also be used to treat safe municipal water According to Welch TP (2000). boiling water kills bacteria as well as other disease-causing 
microorganisms which are commonly found in rivers and lakes at temperatures above $70^{\circ} \mathrm{C}$ within 30 minutes, above $85^{\circ} \mathrm{C}$ within a few minutes, and at boiling point $100{ }^{\circ} \mathrm{C}$ most pathogens will be killed, excluding certain pathogens and their spores, which must be heated to $118^{\circ} \mathrm{C}$ e.g. Clostridium botulinum. This can be achieved by using a pressure cooker, as regular boiling will not heat water past $100{ }^{\circ} \mathrm{C}$ at sea level. Other methods are portable pump filters filter 5,000 to 50,000 litres per cartridge, removing pathogens down to the $0.2-0.3$ micrometer $(\mu \mathrm{m})$ range Water filters can be made on-site using local materials such as grass, charcoal (e.g. from firewood burned in a special way).

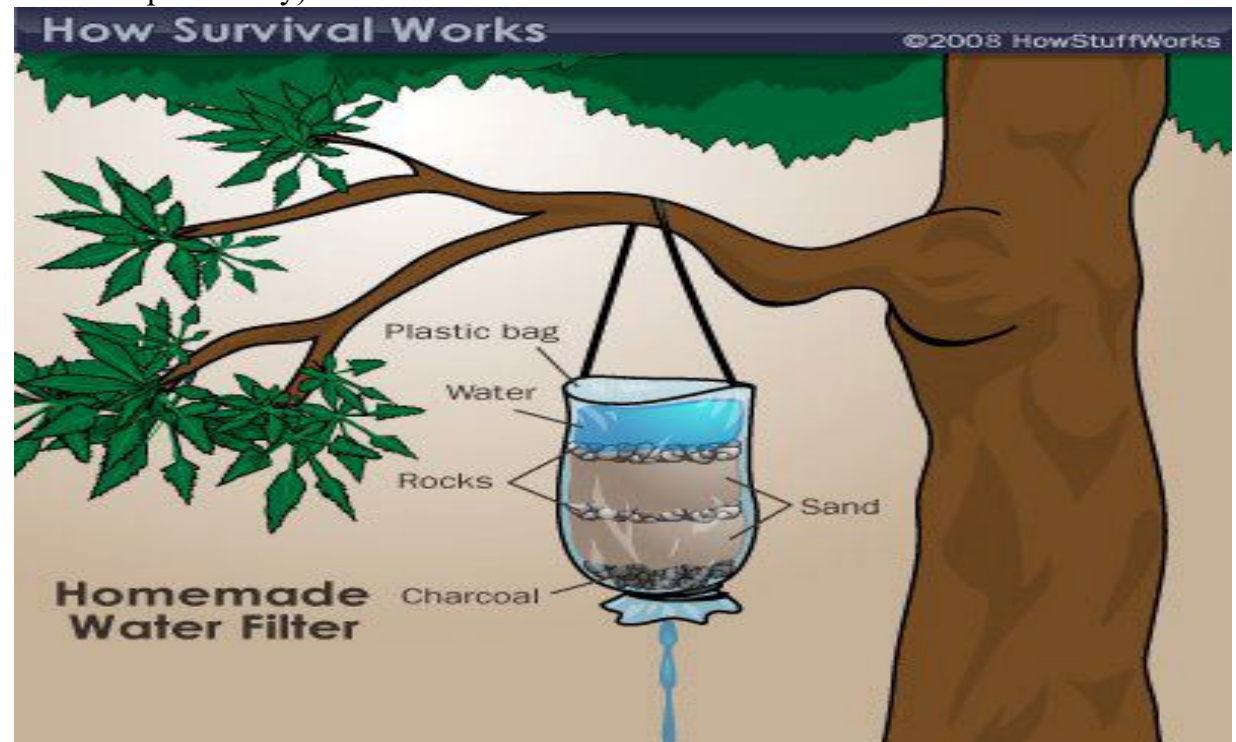

Figure 1: $\quad$ Gathering burnt bricks for water filtration. Curtsey Alibaba.com products/water treatment bricks

Such filters do little, if anything, to mitigate pathogens and other harmful constituents and can give a false sense of security that the water so produced is potable. Water processed through improvised filters should be subsequently boiled to render it safe for consumption. Granular activated carbon filtering utilizes a form of activated carbon with a high surface area, and adsorbs many compounds, including many toxic compounds and removes other bacteria and protozoa, such as Cryptosporidium and Giardia lamblia Water passing through activated carbon is commonly used in concert with hand pumped filters to address organic contamination, taste, or objectionable odors. Activated carbon filters are usually used as secondary means to complement another purification technique. Activated charcoal can remove chlorine, chlorine dioxide and sodium hypochlorite (bleach ) mostly used in water disinfection against pathogens, and would not, in general, be used without careful thought after chemical disinfection

Small, hand-pumps called the Life Saver bottle, filters with a combination of hand pump, filter membranes and a charcoal filter. This new system removes particles larger than $15 \mathrm{~nm}$, and thus is able to filter-out viruses. A similar system, the Life Straw, removes particles larger than 15 microns with a set of two membrane filters and a carbon filter. The polymer membrane filters are impregnated with antimicrobial halogens to kill pathogens, and the carbon filter is impregnated with silver to inactivate residual halogens from the membrane filters.

\subsection{Chemical Disinfection}

4 .1.1 Iodine post-treatment on filter elements kills viruses and the smaller bacteria that cannot be filtered out, but the unpleasant taste imparted to the water, as well as possible adverse health effects when ingested over protracted periods discourages its use for water purification. It is commonly added to water as a solution, in crystallized form, or in tablets containing tetraglycine hydroperiodide that release $8 \mathrm{mg}$ of iodine per tablet. The iodine kills many but not all of the most common pathogens present in natural fresh water sources. Carrying iodine for water purification is an imperfect but lightweight solution for those in need of field purification of drinking water a potentially lower cost alternative to using iodine based water purification tablets is the use of iodine crystals, commonly sold under the Polar Pure name. A small amount of water is poured into a small glass bottle containing the iodine crystals; one waits 30 minutes, and then pours off only the amount of liquid solution needed into a larger source of untreated water such as a canteen. After waiting a small amount of time, lengthened if treating cold water instead of warm water, potable water is then available from the treated water. An advantage of using iodine crystals is that only a small amount of iodine is dissolved from the iodine crystals at each use, giving this method of treating water a capability for treating very large amounts of water, typically over 2,000 gallons, with but a small bottle of crystals. Ingestion of the actual iodine crystals must be avoided when using this method. Rockwell, Robert L. (2003). 
4.1.2 Chlorine in water is more than three times more effective as a disinfectant against Escherichia coli than an equivalent concentration of iodine. Halazone tablets were thus commonly used during World War II by U.S. soldiers for portable water purification, even being included in accessory packs for C-rations until 1945. The primary limitation of halazone tablets was the very short usable life of opened bottles of halazone tablets, typically 3 days or less, unlike iodine based tablets which have a usable open bottle life of 3 months. Chlorine bleach tablets give a more stable platform for disinfecting the water than liquid bleach (sodium hypochlorite) as the liquid version tends to degrade with age and give unregulated results. Chlorine-based bleach may nonetheless safely be used for short term emergency water disinfection. Two drops of unscented $5 \%$ bleach can be added per liter of clear water, and then allowed to stand covered for 30 to 60 minutes. After this treatment, the water may be left open to reduce the chlorine smell and taste. Guidelines are available online for effective emergency use of bleach to render unsafe water potable. The Centers for Disease Control \& Prevention (CDC) and Population Services International (PSI) promote a similar product (a $0.5 \%-1.5 \%$ sodium hypochlorite solution) as part of their Safe Water System (SWS) strategy. The product is sold in developing countries under local brand names specifically for the purpose of disinfecting drinking water (CDC: SWSPSI: SWS )

\section{Conclusion}

It is apparent that the various options at our disposal in water purification agrees with our hopes toward s making portable water available sufficient by 2030 . This is achievable by intense survey of our natural environment for simple, accessible water sources, carrying out the various analyses to ascertain the most suitable treatment, possibly test running the process and application on an industrial or domestic scale. This no doubt requires mass education at that level but achievable especially with the present man power available and that in expectation. That includes supervision which dates back to sanitary inspectors days which was very effective.

\section{Acknowledgement}

We acknowledge with deep appreciation the role played on this work by Department of Chemistry University of Agriculture Makurdi and Department of Science Laboratory Technology Nasarawa State University Keffi as well as Benue State Water Board, Makurdi Laboratory.

\section{References}

${ }^{\wedge}$ Beetseh, C.I., Adulugba, M. (2013). Journal of Natural Sciences Research Quality Appraisal of Old and New (Greater) Water Works in Makurdi. Benue State Nigeria $\quad$ www.iiste.org ISSN 2224-3186 (Paper) ISSN 22250921 (Online) Vol.3, No.12, 2013

$\wedge$ J, Gilmore Green,Engineering (2013).

$\wedge$ The lack of drinking water and dangers of water boreholes Africa Political and Economic Strategic Center Afripol March 24, 2010

$\wedge$ Welch TP (2000). "Risk of giardiasis from consumption of wilderness water in North America: a systematic review of epidemiologic data". International Journal of Infectious Diseases 4 (2): 100-3. doi:10.1016/S12019712(00)90102-4. PMID 10737847.

$\wedge$ Rockwell, Robert L. (4 June 2003). "Giardia lamblia and Giardiasis With Particular Attention to the Sierra Nevada". http://www.peakclimbing.org/articles/giardia 2003.pdf. Retrieved 26 November 2009.

^ LeMar et al, HJ. "Department of Medicine, Madigan Army Medical Center, Tacoma, Washington 98431.". Journal of Clinical Endocrinology \& Metabolism, Vol 80, 220-223, Copyright (C) 1995. Endocrine Society. http://jcem.endojournals.org/cgi/content/abstract/80/1/220. Retrieved 20 Mar 2010.

^ Qiu X, Sundin GW, Chai B, Tiedje JM (November 2004). "Survival of Shewanella oneidensis MR-1 after UV radiation exposure". Applied and Environmental Microbiology 70 (11): 6435-43. doi:10.1128/AEM.70.11.64356443.2004. PMC 525172. http://www.pubmedcentral.nih.gov/articlerender.fcgi?tool=pmcentrez\&artid=525172.

$\wedge$ USEPA, Ultraviolet Disinfection Guidance Manual for the final LT2ESWTR, Nov 2006

^ "National Primary Drinking Water Regulations: Long Term 2 Enhanced Surface Water Treatment Rule". Federal Register (U.S. Environmental Protection Agency) $71 \quad$ (3): 783. 05-Jan-2006. http://www.epa.gov/fedrgstr/EPA-WATER/2006/January/Day-05/w04c.htm. Retrieved 17-Apr-2010.

^ Mofidi, AA; Meyer EA, Wallis PM, Chou CL, Meyer BP, Ramalinham S, Coffey BM (2002-Apr). "The effect of UV light on the inactivation of Giardia lamblia and Giardia muris cysts as determined by animal infectivity assay". Water Research 36 (8).

^ Campbell, Andrew; Wallis, Peter (2002-Feb). "The effect of UV irradiation on human-derived Giardia lamblia cysts". Water Research 36 (4): 963-969. doi:10.1016/S0043-1354(01)00309-8. PMID 11848367.

$\wedge$ Linden, KG; Shin GA, Faubert G, Cairns W, Sobsey MD (2002-06-01). "UV disinfection of Giardia lamblia cysts in water". Environmental Science and Technology 36 (11). 
Locations of Research Water Sources

\begin{tabular}{|l|c|c|}
\hline Sources & No sampled in Keffi & No sampled Makurdi \\
\hline Water hawkers & - & 1 \\
\hline Public supply & 1 & 1 \\
\hline Tube wells & 1 & 1 \\
\hline Bore holes & 2 & 1 \\
\hline water harvesters & - & 2 \\
\hline River water direct fetching & - & 2 \\
\hline
\end{tabular}

Results (Average values from 3 composite samples each)

\begin{tabular}{|c|c|c|c|c|c|c|c|c|c|}
\hline Water source & Location & Temp ${ }^{\circ} \mathrm{C}$ & $\begin{array}{l}\text { Color } \\
\text { Pt.co }\end{array}$ & $\begin{array}{l}\text { Conductivity } \\
\text { Mhos }\end{array}$ & pH & $\begin{array}{l}\text { Total } \\
\text { Hardness } \\
\text { mg/L }\end{array}$ & $\begin{array}{l}\text { Total } \\
\text { dissolved } \\
\text { Solids } \\
\text { mg/L } \\
\end{array}$ & $\begin{array}{l}\text { Dissolved } \\
\text { Oxygen }\end{array}$ & \begin{tabular}{lr}
\multicolumn{2}{l}{ Bacterial } \\
Load & per \\
100 & ml \\
water & \\
\end{tabular} \\
\hline TUBE WELL & $\begin{array}{ll}\begin{array}{l}\text { KANSHIO village } \\
\text { Makurdi }\end{array} & \\
\end{array}$ & 29 & 280 & 60 & 6.2 & 15 & 170 & 5.2 & 70 \\
\hline $\begin{array}{l}\text { WATER } \\
\text { HARVESTERS } \\
\end{array}$ & $\begin{array}{l}\text { Logo village } \\
\text { MAKURDI }\end{array}$ & 30 & 25 & 120 & 5.9 & 17 & 120 & 4.3 & 75 \\
\hline $\begin{array}{l}\text { PUBLIC WATER } \\
\text { SUPPLY }\end{array}$ & $\begin{array}{ll}\text { KEFFI } & \text { HOTELS } \\
\text { KEFFI } & \\
\end{array}$ & 25 & 0 & 0 & 6.8 & 12 & 60 & 7.8 & 4 \\
\hline BORE HOLE & $\begin{array}{l}\text { APEAKAA GBOKO } \\
\text { ROAD MAKURDI }\end{array}$ & 28 & 0 & 70 & 6.8 & 14 & 90 & 4.5 & 6 \\
\hline $\begin{array}{l}\text { PUBLIC } \\
\text { SUPPLY }\end{array}$ & $\begin{array}{ll}\text { MAKURDI } & \text { CLUB } \\
\text { MAKURDI } & \end{array}$ & 28 & 10 & 0 & 6.9 & 10 & 40 & 8.5 & 3 \\
\hline TUBE WELL & $\begin{array}{l}\text { BLOCK } \\
\text { MOULDING } \\
\text { FACTORY SABON } \\
\text { GARI KEFFI }\end{array}$ & 27 & 10 & 40 & 5.8 & 12 & 170 & & 6 \\
\hline $\begin{array}{l}\text { DIRECT RIVER } \\
\text { WATER } \\
\text { FETCHING }\end{array}$ & $\begin{array}{l}\text { WADATA } \\
\text { MARKET } \\
\text { RIVERSIDE } \\
\text { MAKURDI } \\
\end{array}$ & 26 & 170 & 92 & 5.7 & 18 & 160 & & 80 \\
\hline $\begin{array}{l}\text { BORE HOLE } \\
\text { UNIVERSITY } \\
\text { CAMPUS }\end{array}$ & $\begin{array}{lc}\text { NSUK } & \text { UTILITY } \\
\text { WATER KEFFI }\end{array}$ & 24 & 290 & 150 & 6.7 & 19 & 150 & & 78 \\
\hline BOLE HOLE & $\begin{array}{l}\text { SHAMAKI } \\
\text { VILLAGE SABON } \\
\text { GERI KEFFI }\end{array}$ & 24 & 20 & 70 & 5.5 & 18 & 170 & & 6 \\
\hline $\begin{array}{l}\text { WATER } \\
\text { HARVESTERS }\end{array}$ & $\begin{array}{lr}\text { YOGBO } & \text { LEKE } \\
\text { GBOKO } & \text { ROAD } \\
\text { MAKURDI } & \end{array}$ & 26 & 40 & 50 & 6.8 & 17 & 12 & & 54 \\
\hline $\begin{array}{l}\text { WATER } \\
\text { HAWKERS }\end{array}$ & $\begin{array}{lr}\text { HEAVY } & \text { DUTY } \\
\text { PARK } & \text { NORTH } \\
\text { BANK MAKURDI }\end{array}$ & 27 & 30 & 40 & 5.1 & 16 & 90 & & 10 \\
\hline $\begin{array}{l}\text { DIRECT WATER } \\
\text { FETCHING }\end{array}$ & $\begin{array}{l}\text { RIVER BENUE } \\
\text { WURUKUM } \\
\text { MAKURDI }\end{array}$ & 25 & 160 & 180 & 5.7 & 19 & 170 & & 70 \\
\hline $\begin{array}{ll}\text { WHO/NIGERIA } \\
\text { GDW } & \text { Standards } \\
2005 . & \end{array}$ & & 28 & 50 & 1.4 & 6.5 & 14 & 150 & & 0 \\
\hline & & & & & 8.5 & & & & \\
\hline
\end{tabular}

